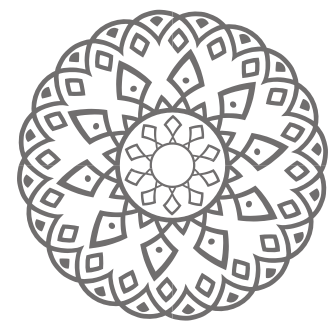

\title{
The Implementation of Sharia in Aceh: Between The Ideal and Factual ACHIEVEMENTS
}

Muhammad Amin Suma, Ridwan Nurdin, Irfan Khairul Umam

\begin{abstract}
Abstrak: Aceh menjadi satu-satunya provinsi di Indonesia yang menerapkan syariat Islam secara formal. Penelitian ini mengkaji penerapan syariah di Aceh dengan membandingkan antara yang ideal sebagaimana diharapkan dan yang faktual. Dengan menggunakan pendekatan kualitatif dan sosiolegal, data diperoleh melalui wawancara dengan Majelis Permusyawaratan Ulama, Dinas Syariah, akademisi, dan tokoh masyarakat. Selain itu, observasi dilakukan untuk melihat pelaksanaan hukuman cambuk. Hasil penelitian ini menunjukkan bahwa implementasi syariah di Aceh sudah didukung dengan institusi syariah (MPU dan Dinas Syariah), dan tokoh agama, masyarakat. Adanya eksekusi bagi pelanggar hukum menguatkan pelaksanaa syariah di daerah itu. Akan tetapi, ada pula aspek-aspek yang perlu ditingkatkan, yaitu peran penegak hukum seperti polisi, jaksa, hakim, dan juga keberlangsungan sosialisasi kepada masyarakat.
\end{abstract}

Kata kunci: Syariah, Aceh, Majelis Permusyawaratan Ulama, Dinas Syariah 
Abstract: Aceh becomes the only region in Indonesia, where Islamic law is formally implemented. This paper aims at discussing the implementation of sharia in Aceh, to compare between its ideal and factual achievements. Employing a qualitative socio-legal approach, data is obtained from interviews with the chairperson of Ulama's Consultative Assembly (Majelis Permusyawaratan Ulama), head of Sharia Office (Dinas Syariah), scholars, and community leaders. Apart from that, an observation was undertaken to record the process of whipping punishment. This study finds out that sharia implementation in Aceh has been sufficiently supported by sharia institutions (MPU and Sharia Office), religious figures, community, and available punishment execution for the violators. However, some aspects need to be improved, especially those that are related to the role of other law enforcers such as police, prosecutors, and judges; and sustainable socialization.

Keywords: Sharia, Aceh, Ulama Consultative Assembly, Sharia Office 


\section{Introduction}

The desire to carry out sharia in Indonesia has begun since the Reform Era (Masykuri Abdillah, 2005: 1-9). Sharia is implemented in a formal way or under a legal umbrella. This means that sharia is implemented within the corridor of the existing legisl system. In another sense, the sharia strengthens the legal system in Indonesia. This condition is undoubtedly different if the sharia is implemented by an individual or society. In Islamic teaching, the implementation of sharia requires the role of the state because in Islam the punishment can only be carried out by the state, not individuals or society (Samsul Bahri: 2007, 157-158).

The implementation of sharia in Aceh is the implementation of qānūns. Qànūn is a regional regulation issued jointly by the Governor and the People Representatives of Aceh. Therefore, sharia is not the law understood by many people. Even though the sources in the formulation of the qānūn are derived from variety and sub-substantial references, the reference of the state and legal apparatus is the qainüns.

Al Yasa Abubakar (2019 p.72-75) stated, "there are four things considered positive related to the implementation of sharia in Aceh. First, allowing the implementation of sharia in Aceh within the Indonesian National Law system is a gift. Second, because the enforcement of sharia has been a prolonged struggle since the independence of the Republic of Indonesia, therefore, its achievements are not important because the process of "becoming" takes time. Third, the implementation of sharia in the form of regulations or national law is new and has no precedent. Fourth, the sharia is implemented through various contexts. If the formal implementation is unsuccessful, then, the implementation is carried out in the form of a cultural approach and community activities. This opportunity is undoubtedly due to the policies made by the Government of Aceh.”

The implementation of sharia as exemplified by Aceh is rather new because examples that are referred to in the modern context tend to be non-existent. Thus, the Sharia in Aceh is designed for the needs of the Acehnese people, and started with a cultural approach. The wearing of hijäb and restrictions on promiscuity is the initial stages of the application of sharia in Aceh. Some of the earliest qänüns issued 
are Qànūn No. 11 of 2002 concerning the Implementation of Sharia in the Matters related to Creed or Aqidah, Worship, and the Symbols of Islam; Qānun No. 12 of 2003 concerning the Prohibition of Khamar (alcoholic beverages); Qànün No. 13 of 2003 concerning the Prohibition of Maysir (gambling); Qānūn No. 14 of 2003 concerning the Prohibition of Khalwat (proximity between unmarried man and woman) and Qänün No. 7 of 2004 concerning Alms.

At the early stage of sharia implementation, the campaign about the obligation of wearing a hijab was intensively carried out by an institution called Wilayat al Hisbah. Almost every day and in every city corner, the Wilàyat al Hisbah conducted surveillance and raids to women who did not wear hijäb. The arrests were made to those who were caught in gambling and drinking liquor, in which the reports could be found almost every day in local newspapers. All efforts made by the Wilayat al Hisbah relatively have changed the atmosphere of the social life of the Acehnese society (Syahrizal Abbas, 2009: 64-71).

To implement the qānūn, new sharia institutions are established as a result of the needs and state responsibility in implementing the sharia. This responsibility covers the aspects of concepts, policies, supervision and the creation of justice. This is realized through the establishment of Sharia Office (Dinas Syariah) as the representative of the Governor in determining the concepts and policies of sharia in Aceh. In addition, the Wilayat al Hisbah acts as the supervisory institution. At first, the Wilayat al Hisbah was under the Sharia Office, but over time, the Wiläyat al Hisbah becomes a part of the police unit (Al Yasa Abubakar: 2003, 45-51).

In line with the issuance of Law No. 44 of 1999 concerning the Aceh Privileges in the Fields of Religion, Education, and Custom. Along with the implementation of sharia, several institutions were established, such as the Regional Education Assembly (now Aceh) institutions for educational field, the Religious Sector, the Ulama Consultative Assembly, Bait al-Māl Institutions, and Aceh Adat (Custom) Assembly.

Besides, the change in the name and authority of the Indonesian Ulama Assembly to the Ulama Consultative Assembly further affirmed the position of Sharia in Aceh. The Ulama Consultative Assembly becomes the partner and referee for the Acehnese local government, as the government will consult with the Assembly for sharia matters. 
Ulama Consultative Assembly is a partner and referee in Government policy in Aceh. Every Aceh government policy will always ask the view of the Ulama Consultative Assembly. With this, efforts to escort sharia will continue. Procedurally, the content of qānūn will be approved Assembly before submitted to the Acehnese People Representative. This means that the role of the Ulama Consultative Assembly is essential.

The members of the Ulama Consultative Assembly are a group of ulama from all over Aceh. The Assembly consists of the primary team and the respective ulama. The qainun becomes a part of the professionalism of the Ulama Consultative Assembly, and other parties involved in designing the qānun, such as academics and practitioners. Strengthening the qānum has continuously maintained along with the development and changes in society. The implementation of sharia through qūnūn, of course, is inseparable from the nature of Islamic teaching, especially in terms of its ability to be applied in a heterogeneous social system (Yusuf Qardhawi 2003: 162-214).

Sharia is unique. Among the uniqueness of sharia is the possible acceptability of its enforcement by a society, regionally, nationally, and internationally. The concrete instance is the differences in the scope of sharia implemented in the context of the Unitary State of the Republic of Indonesia in general, and a broader scope of sharia implementation in Aceh. The latest is not the same as the implementation of sharia in other regions in Indonesia, which does not involve a formal sharia implementation through regional regulations of qānūns. Another difference is that in other regions the sharia has not been implemented comprehensively. In contrast, in Aceh, the sharia is applied comprehensively covering many aspects of life (Rusjdi Ali Muhammad \& Dedy Sumardi 2012: 42).

The commitment to fully implement sharia in Aceh can be seen in the enactment of qainūn as part of the regional regulations. Especially in the past 20 years, the sharia was demanded by the Acehnese people. Sharia in Aceh has become the tradition of its people in many aspects of their lives, such as theological, historical, sociological, juridical, political, and futurological aspects. They go hand in hand in the efforts for sharia implementation. This implementation is initially marked by the promulgation of Act No. 44 of 1999 concerning Aceh's Special Autonomy, along with Regional Regulation No. 5 of 2000 concerning 
the Implementation of Sharia in Aceh. The province, known as Porch of Mecca (Serambi Mekkah), has dozens of qānün and other shariabased regulations concerning many aspects of human life (Ridwan Hasan 2013: 85).

\section{Overview of Aceh}

Compared to other provinces in Indonesia, Aceh is one of the relatively old provinces, even compared to the age of Indonesia. The history of Aceh can be traced from the beginning of it becoming "a sovereign Sultanate, with its advancement, strength, and significant influence on other regions around it." The history recorded that, in Aceh, Islamic kingdoms or Sultanates was established and ruled over long periods. These included the Sultanate of Raja Ibrahim or Sultan Ali Al-Mughayat Syah (1507-1522); Sultan Salahuddin Ri'ayat Syah or Al-Qahhar (1537 - 1568); Sultan Husin (1568 - 1575); Sultan Alauddin Mansur Syah (1577 - 1586); Sultan Alauddin Ri'ayat Syah (1588 - 1604); and Sultan Ali Ri'ayat Syah (1604 - 1607); until then the rise of Sultan Iskandar Muda in 1607 and beyond (Ridwan Hasan, 2013: 1-32).

With the Western (European) colonialism and the weakening of many Islamic Kingdom in the Archipelago (Nusantara), including the Aceh Sultanate, all of them voluntarily declared to integrate and become parts of a state called Indonesia. After considering all aspects, such as politics, economic, and the ideal of Acehnese people, they remained to keep their firm determination to have their "own state and government" outside the Unitary Republic of Indonesia.

Previously, Aceh had united for long enough with the other Indonesian regions, especially with the North part of Sumatera. The Province of Nanggroe Aceh Darussalam was firstly established in 1959, based on the Decree of the Prime Minister of the Republic of Indonesia No. 1/ MISSI/ 1959. Since 26 May 1959, the Level 1 Swatantra Region or the Province of Aceh was granted the status of "Special Region" with the full title "The Province of Special Region Aceh". Since then, Aceh Province still formally and constitutionally becomes an integral part of the Unitary Republic of Indonesia.

Aceh covers 58.377 square kilometre area. It is located close to the Andaman and Nicobar Islands in India, separated by the Andaman sea. 
Aceh is bordered by the Bay of Bengal to the north, the Indian Ocean to the west, the Straits of Malacca to the east, and North Sumatra to the southeast and south. The province is called "The Porch of Mecca" because of its population obedience to the teachings of Islam. Until 2019, Aceh populated by 5.281 .891 people, spread in 23 districts or cities. These include (1) West Aceh, (2) Southwest Aceh, (3) Greater Aceh, (4) Aceh Jaya, (5) South Aceh, (6) Aceh Singkil, (7) Aceh Tamiang, (8) Central Aceh, (9) Southeast Aceh, (10) East Aceh, (11) North Aceh, (12) Bener Meriah, (13) Bireun, (14) Gayo Lues, (15) Nagan Raya, (16) Pidie, (17) Pidie Jaya, (18) Simeulue, (19) Banda Aceh, (20) Langsa, (21) Lhokseumawe, (22) Sabang, and (23) Subulussalam.

Aceh was given the status of Special Province, similar to Yogyakarta. However, the specialty of these two provinces is different in terms of the substance and the privileges are given. Unfortunately, the speciality given Yogyakarta has been stable and benefited to its development. This is different from the experience of Aceh with its speciality but face complex issues and turbulence in many aspects. Several issues led to the difficulties in implementing the Specialty of Aceh, which is mainly political. Since the special status was granted in 1959, the Aceh province still could not enjoy it thoroughly. This happened during the Old Order (1945-1967) to the New Order (1967-1998) regimes. The changes in the government, local and national, did not change the situation in Aceh.

Moreover, the armed conflict in Aceh has a broad political impact, which resulted in the delay of the Aceh development. In general, Acehnese people, living in Aceh, outside Aceh, or even abroad, had almost "never" enjoyed the atmosphere of independence and peace in a real sense. This means free from fear and the threat of armed violence. This contradicts with the ideal of the Indonesian independence, which has been fully supported by the people of Aceh, as stipulated in the Preamble of the 1945 Constitution:

"Pursuant to which, to form a Government of the State of Indonesia that shall protect the whole people of Indonesia and the entire homeland of Indonesia, and to advance general prosperity, to develop the nation's intellectual life, and to contribute to the implementation of a world order based on freedom, lasting peace and social justice, Indonesia's National Independence shall be laid down in a Constitution of the State of Indonesia, which is to be established as the State of the 
Republic of Indonesia with the sovereignty of the people and based on the belief in the One and Only God, on just and civilized humanity, on the unity of Indonesia and on the democratic rule that is guided by the strength of wisdom resulting from deliberation/representation, to realize social justice for all the people of Indonesia."

The clause that states "social justice", in the preamble of the 1945 Constitution, certainly applies also to the Acehnese people. However, it had been unfortunate to the Acehnese people that they faced conflicts, including political and economic conflicts to the conflict of ideology. This condition was exacerbated when the tsunami hit Aceh in December 2004. Despite the hardness faced by the Acehnese, this event has led to positive impacts, and valuable lessons for the Acehnese people, Indonesia people, and all people in the world. The tsunami was undoubtedly a traumatic event. To remember the tragedy, the government built The Aceh Tsunami Museum in 2009. This is a symbolic monument so that the Tsunami in Aceh and the Indian Ocean can produce 1001 science and knowledge.

The New Order Regime issued the Military Operational Area Status for Aceh to deal with the prolonged standing conflicts. In solving the conflicts, the government of Indonesia involve national and international institutions and address issues that led to the conflicts. Apart from that, it is known that the Acehnese people 'demanded'the implementation of Islamic law in Aceh comprehensively (kafab\}) in their social life and other aspects of life. This also becomes a logical consequence of the recognition of Indonesia over the Aceh special status determined in 1959 and the implementation of Law No. 44 of 1999 concerning the Special Status of Aceh Province.

"The special status of Aceh is applied several aspects, such as: "Organizing the [Aceh] Privileges includes: (a) Organizing religious life (b) Organizing traditional life (c) Organizing education, and (d) Role of ulama in establishing regional policies. Specifically on "The implementation of religious life in the [Aceh] Region is manifested in the form of the implementation of Islamic Sharia for its adherents in the community." "Regions develop and regulate the organization of religious life as referred to in paragraph (1) while maintaining harmony between religions." It was further emphasized that: "The implementation of religious life in [Aceh] is manifested in the form of the implementation of 
Islamic Sharia for its adherents in the community." "Regions develop and regulate the organization of religious life as referred to in paragraph (2) while maintaining harmony between religions." (The Act Number 44 of 1999 concerning Aceh Privileges article 3 paragraph (1))

\section{Sharia and Maqasid Shari'a}

Sharia and Maqasid sharia are two different terms in Islamic Law, even though they are often related to each other. Etymologically, sharia is rooted from shara'a-yashra'u-shar'ān-. It means to make regulations or laws, as in the expression: "shara'a li-al-qaumī = sannā sharīatān $=$ (someone or institution) make regulations or laws for a people or nation. Another meaning of the word shara'a is to open or show, as in the expression shara'a lahüm al-tharīqa, ayazhharahū = he (someone) has opened or has shown (something) to them. The word shara'a can also be translated into starting, nearing, planning, outlining, directing, lifting, peeling, going into or plunging into it, drinking with hands, clearly, and brightly (Muhammad Yusuf Musa: 2014, 1-15).

Al-shar'u, or al-sharī'a which is the noun (masdar) form of shara'a in the text as well as the context of legal science and legislation means that it is a rule or law (al-qūnūn). Meanwhile, the word sharia (al-sharīah) can also be and is commonly referred to as al-shir'a or al-sharía. In the legal literature, especially applied law, the term sharia (al-shari'ah alIslamiyah; shari'ah) is commonly equated with fiqh, qanūn, and Islamic law. According to al-Imam al-Akbar or Grand Sheikh Al-Azhar period 1958-1963, Mahmud Syaltut (1893 - 1963 AD), sharia is: "a series of rules (legislation) set by Allah, or [at least] the principles are prescribed to be taken [and applied] by humans in regulating the relationship between him/herself and God (Rabb), the internal relationship between Muslims, relationships between humans (Muslims and non-Muslims), the relationship with the environment, and relationships with other lives in general (Mahmud Syaltut, 2000: 12). In the Aceh Qānun s, the formulation of sharia is briefly defined as "a guide to the teachings of Islam in all aspects of life."

Sharia, as stated above, certainly has goals or targets to be achieved. More than that, shari'a has an ideal or vision that is more popular as the maqasid al-shari'a. Maqāsid is the plural form of maqsad, derived from the word qashada - yaqshidu - qashdan. It means meaning 
intention, intention, target, goal (al-niyyatu, al-qashdu, al-ghāyatu, wa-al-ghardhu). Maqsad can also be interpreted as a straight way (thariqun mustaqimun), and al-qasdu can also mean simplicity, the opposite of excessive (dhidhdh al-iqräth). Other meanings of maqsad are straight paths (thariqun qasdun); direct paths (opposite of excessive or exaggeration (dhidhdh al-iqräth). The word al-maqsad has a similar meaning with al-qasdu; that is, the purpose, goal, or destination (Yusuf al-Qardhawi 2003: 60-70).

Rafiq Yunus al-Misri equates maqāsid with masalih when he states "al-maqāsid hiya al-masālih = maqūṣid is none other than mașälib". (Rafiq Yunus al-Mishriy, tt: 11) So, maqūșid = masālih, and masālih = maqāsid. Muhammad al-Zuhayli, in his book Huqūq al-Insān fi-alIsläm also asserted that al-haqq is a benefit (maslahah) and maslahah is benefit (Muhammad Zuhaily, tt: 5). Something is not seen as a right unless it has received legal recognition, or the provisions of sara and religion, or legislation. The purpose of sending down the Quran and the Prophet is in conjunction with sharia, which, as a legal system, aims at realizing the benefit of human beings (li-tahqīqi mașālih al-nās). In other words, al-masālih or al-manfáa is the main target of sharia (almașālih hiya maqūṣid al-sharīah).

Other terms commonly used by experts in referring to maqāsid al sharia are maqūșid ahkam (maqūshid al-ahkām) and "ghayāh al-ahkām," which more or less have the same meaning with maquạid al sharia, namely the meaning and purpose of (establishment) of sharia. Maqāsid al sharia is all objectives or goals to be achieved by sharia. To achieve the goals or objectives of sharia, Allah promulgates the sharia in the form of rules or norms (al-maqūsìid hiya al-aghradh alläti li-ajlīha shara'a alshari'äh). In essence, sharia is an object (goal) to be achieved and at the same time as a tool or way used to achieve that goal. In short, sharia is both objectives and tools (Abdullah bin Yusuf, tt: 300).

Muhammad Abu Zahra (1898 - 1974), who is more accustomed to using the term maqūsid al-Ahkam or maquạid al-Ahkam alsharizyyah, states that the objective/ target/ primary target of sharia laws is (upholding) affection and justice (al-rahmah wa-al-is) in all aspects of life. Maqūsid shariah or maqūsid ahkam does not have to rely on a certain degree/ level to be met. This is because, in reality, not all kind of maquasid of sharia is fundamental and therefore not it is 
not an absolute obligatory. Islamic jurists including al-Syathibi (730 $790 \mathrm{H} / 1328$ - 1388 AD) (al-Syathibi, tt: 1-29) and so on had been accustomed to differentiating human needs into three levels, namely, primary(dharuriyyat; luxuries), secondary (hajiyat; needs), and tertiary (tahsiniyat / takmiliyat; necessities) which by Jasser Auda was put into a diagram (Jasser Audah, 2010: 3).

Three levels of human needs formulated above, at the same time, show the hierarchy of human needs that are tiered into primary needs, which are urgent; secondary needs (hajjat), and the tertiary needs, which are the lowest (tahsiniat or takmiliat). Even so, experts have also agreed that meeting the above three levels of human needs is permissible to achieve a complete and perfect level of life, if possible (Yusuf Hamid Alim, 1994: 133-173).

Sorting and choosing the priority scale of human needs above is used when a person or group (family, the community even nation and state) is unable to meet three needs at the same time (all at once). In this case, they must choose the most important ones. In Aceh, it seems that the qanun is intended to fulfil all human needs ranging from the daruriyat to hajjiyat and tahsiniat / takmiliyat. This can be understood from the number of Qanun s and the affirmation about the purpose of the qānun (Syahrizal Abbas, 2009: 64)

Moreover, Muslim scholars say that the general purpose of Islamic law (al-tashrī 'al-islāmì) is to bring benefits and dispel or refuse damages (jalb al-mașälih wa-daf'u al-mafäsid). Al-mașlāhah is also often called benefit (al-manfáah), al-khair or al-hasanah, which mean good. Meanwhile, mafsadah (al-mafsadah) is often also termed madarat (almadarrah), al-sharr, or al-sayyiah and al-qabihah. That is also why the rules sometimes "jalb al-manafi" wa-dar "al-mafäsid," or "jalb almanafi" wa-daf "al-madharrah" or others.

The needs of dharuriyyat by classical and contemporary scholars are called al-dharuriyyat al-khams or five basic human needs namely: protection of life (hifzh al-nafs), religion (hifzh al-din), intellect (hifzh al-'aql), lineage (bifzh al-nasl / al-'ardh), and property (hifzh al-mal). Every Muslim should inevitably fulfil Al-dharuriyyat al-khams. More than that, Muslims'belief in the notion of Al-dharuriyyat al-khams seems to be final and unchangeable. In fact, along with changes and development in human lives, the concept of al-dharuriyat needs to be 
changed or added as needed. For example, the has been new notions of al-dharuriyyat al-sab'ah (seven primary needs), al-dharuriyyat a-tis'ah (nine primary needs) and so on. This is similar to the development of recitation method of the Quran, with its qirāat sab'ah (seven recitation methods) to qiräat 'ashrah (ten recitation methods), and then qirāat arba'ata 'asyar (fourteen recitation methods) Abdussabur Syahin, 2008: 39-44).

\section{Qānun ization of Sharia}

Qànun is another name for law, regulation, rule, or law book. Qānun ization of sharia, in this study, means the process of turning legal or sharia norms into various forms of state regulation or written legislation as is typical in the contemporary era. According to Abdul Karim Zaidan (1917-2014), there are at least three main reasons for turning sharia into qānun.

First, the implementation of sharia (tathbīq al-syarīah al-Islämiyyah) is viewed by Muslims as an integral part of the religious system and an integral part of their belief. This is why the demand for sharia will be part of the Muslim community, even though struggles, long and gradual process, as well as material expenses, are needed.

Second, written qanun is viewed as something attached to the heart (dhamir) or every community, including the Muslim community, as well as becoming a guarantee for the sustainability of their belief, the soundness of the community, and the result of their thinking for a better future. The qänun becomes more significant in the current digital era, where written law becomes essential.

Third, considering its status as religious law, sharia is compatible with every place and time, because it does not restrict humans'freedom (hurriyah al-insan) in various matters. It becomes unsurprising when an international congress was held in Lahoya - The United States in 1938, western scholars accepted sharia as one of the legal sources, and existing legal system (fiqh al-hayāh; living law). Besides, as an original and independent legal source, sharia is not a system that is taken or adopted from other laws (Abdul Karim Zaydan, 1969: 9-11).

The legalization of Islamic law in the current age happens in almost all countries. Muslims countries, including Indonesia, declare 
themselves as legal states. This is in accordance with the spirit of the Quran that sees the importance of written laws, including qainuns. Indonesian legal system provides extensive and flexible opportunities for Indonesian Muslims to do the Qānun ization of sharia, at least in some instances and certain regions (Samsul Bahri, 2007: 23-25).

The Qānun ization of Islamic law in Indonesia has been long attempts, especially in the early 1970s, marked by the enactment of Law No. 1 of 1974 concerning Marriage. This was followed by Government Regulation No. 9 of 1975 concerning the Implementation of Law No. 1 of 1974 concerning Marriage, and the Presidential Instruction No. 1 of 1991 concerning the Compilation of Islamic Law. This process is continuing until today, along with the needs of the people, as well as the interests of the state.

Along with the enactment of Islamic law in many Islamic and Muslim countries, the Qānun ization of the formalization of sharia by the state has been broadened in terms of its scopes. The scope of sharia has not only covered marriage law or family law but also expanded to other civil law matters. This includes Islamic economic law and sharia finance, which has been popular since the 1990s and 2000s. This shows that the implementation of Islamic law has not been exclusively happened in Aceh, but also in all Indonesian regions, in general. Special for Aceh province, the implementation of Islamic law is widened to criminal law (Islamic criminal law).

\section{The Scope of (Sharia) Qänun in Aceh}

The broader implementation of Sharia as qänun has taken in the Special Province of Aceh, which is in accordance with Law No. 44 of 1999 concerning the Implementation of the Special Status of Aceh Province, Article 3 Paragraph (2). What is meant by privilege (for Aceh province) is an exclusive authority to organize religious life, customs, education, and the role of the ulama in setting regional policies" (Law No. 44 of 1999 Article 1, number 8). Article 4 Paragraph (1) states that "the implementation of religious life in the region is manifested in the form of sharia implementation in the society for its adherents. The region develops and regulates religious life as referred to in paragraph (1) while maintaining harmony between religions" (Law No. 44 of 1999 Article 4 Paragraph (2). 
In the context of following up Law No. 44 of 1999 above, especially Article 3 paragraph (1) letter a and Article 4 paragraph (1) and (2), the Government of Aceh Province has formally implemented sharia since 1999. Until today, there have been at least 15 - 20s Qānun s or shariabased regional regulations enacted by the government of Ace. The Qānun includes the Qānun No. 17 of 2014 concerning Islamic Criminal Law (Jināyat), and Qänun No. 10 of 2005 concerning Technical Guidelines for the Implementation of Whipping Punishments (uqubat), which is the main objects of this study.

The twenty-three qānuns of sharia-based Regional Regulation includes: 1) Aceh Qänun No. 10 of 2002 concerning Sharia Courts; 2) Aceh Qánun No. 11 of 2002 concerning the Implementation of Islamic law in the Field of Aqeeda, Worships, and Symbols of Islam; 3) Aceh Qānun No. 12 of 2003 concerning Alcoholic Beverages and the Like; 4) Aceh Qãnun No. 13 of 2003 concerning Gambling; 5) Aceh Qānun No. 14 of 2003 concerning khalwat (close proximity/ fornication); 6) Aceh Qānun No. 5 of 2007 concerning Baitul Māl; 7) Aceh Qànun No. 9 of 2008 concerning the Cultivation of Adat (Custom) Life and Adat Istiadat; 8) Aceh Qānun No. 10 of 2008 concerning Indigenous Institute; 9) Aceh Qānun No. 2 of 2009 concerning the Ulama Consulvative Assembly; 10) Aceh Qãnun No 7 of 2013 concerning Islamic Criminal Procedure; 11) Aceh Qānun No. 6 of 2014 concerning Islamic Criminal Law; 12) Aceh Qānun No. 8 of 2014 concerning the Principles of Islamic Law; 13) Aceh Qānun No. 9 of 2014 concerning the Establishment of Aceh Islamic Bank; 14) Joint Decree of the Aceh Governor, Police Chief, Attorney General, the Chief Justice of the Province Syar'iyah, Chairman of the Aceh High Court and the Head Office of the Ministry of Justice and Human Rights Aceh Province Number: 26 / MCC / 2004, No. SKEP / 62 / VIII / 2004, No. B-1229 / N.1 / 08/2004, No. W1.D1.UM.01.101116 concerning the Operationalization of the Mahkamah Shar'iyya Authority; 15) Regulation of the Aceh Governor No. 10 of 2005 on Technical Guidelines for Whipping Punishment; 16) Regulation of the Aceh Governor No. 25 of 2007 concering Guidelines for Construction of Worship Place; 17) Regulation of the Aceh Governor No. 41 of 2009 concerning Organizational Structure and Technical Implementation Unit at the Department of Sharia Office of Nanggroe Aceh Darussalam; 
18) Special Province Instruction No. 5/ INSTR/ 1990 concerning the Obligation to Have Skills in Reading Quran and Understanding Local Customs for Elementary School Students; 19) The Instruction of Nanggroe Aceh Darussalam Governor No. 05/ INSTR/ 2000 on the Cultivation of Mosque Management and Meunasah in the Special Province of Aceh; 20) Aceh Governor Instruction No. 06/ INSTR/ 2002 on the Congregational Prayers in Offices/ Institutions/ Law Firms/ Departments in Nanggroe Aceh Darussalam Province; 21) The Instruction of Nanggroe Aceh Darussalam Governor No. 07/ INSTR/ 2008 concerning the Collection of Income Alms on among Civil Servants/ Parties/Employees; 22) Aceh Qänun No. 8 of 2016 concerning Halal Products System; and 23) Aceh Qānun No. 11 of 2018 concerning Islamic Financial Institutions.

From the 23 sharia Qãnuns, which include Regional Regulations, Governor Regulations, and Governor Instructions, only three Qànuns (13\%) directly govern Islamic criminal law. These include Nanggroe Aceh Darussalam Qànun No. 7 of 2013 concerning Islamic Criminal Procedure, Aceh Qānun No. 6 of 2014 concerning Islamic Criminal Law (Jināyat), and Nanggroe Aceh Darussalam Governor Regulation No. 10 of 2005 concerning Technical Instruction for the Implementation of Canning Punishment. The remaining 20 Qänuns (87\%), on the other hand, regulate non-Islamic criminal law matters.

Aceh Qànun No. 6 of 2014 concerning Islamic Criminal Law consists of 10 Chapters and 74 Articles. Apart from regulating jināyat, budüd, ta'zir, restitution, other matters regulated include the prohibition of khamr (alcoholic beverages), maysir or gambling, khalwat, ikhtilat, adultery, sexual harassment, liwath, rape, and others. Meanwhile, Aceh Qānun No 7 of 2013 concerning Islamic Criminal Procedures consists of 23 Chapters and 286 Articles. This regulates matters related to General Provisions (Chapter I), Principles and Objectives (Chapter II), Scope of the Applicability of Qānun (Chapter III), Investigators, Investigators and Public Disciplines (Chapter IV) Arrest, Detention, Body Search, Entering Houses, and Examination of Letters (Chapter V), Suspects and Defendants (Chapter VI), Legal Aid (Chapter VII), Minutes (Section VIII), Pledge (Chapter VIIII), Powers To Prosecute (Chapter X), Connectivity (XI), Compensation and Rehabilitation (chapter XII), Compensation Lawsuit Merger (Chapter XIII), Initial 
Investigation and Investigation (Chapter XIV), Prosecution (Chapter XV), Examination in Court Session (Chapter XVI), Regular Legal Remedies (Chapter XVII), Outstanding Legal Remedies (Chapter XVIII), Implementation of Court Decisions (Chapter XVIII), Monitoring and Observation of Court Decision Implementation (Chapter XX), Funding (Chapter XXI), and Transitional Provisions (Chapter XXII), Final Provisions (Chapter XXIII).

Law on canning is considered new because the Indonesian legal system does not regulate it. The Governor of Nanggroe Aceh Darussalam issued Governor Regulation No. 10 of 2005 concerning Technical Guidelines for the Implementation of the Caning Punishment $\left(U_{q u} \bar{u} a t\right)$. This regulation consists of 17 Articles governing technical matters for the implementation of caning punishment. Caning punishment is a kind of corporal punishment imposed by the law by caning of the convicts.

In contrast to other sentences, canning punishment technically is carried out in an open space, witnessed by people, attended by prosecutors and doctors. During the canning, a convict sits on a mat, sized at least $3 \times 3$ meters. The distance between a convict and the executioner is between 0,07 meter to 1 meter, with the executioner standing on the left side of the convict. The executioner hits the back (shoulder to hip) of the convict. The distance between the caning spot and the witnesses is 10 meters.

Governor Regulation No. 10 of 2005 also regulates the condition of convicts and executioners. For example, before carrying out caning, a convict's health condition is examined by a doctor. The lack of health condition leads to the postpone of caning punishment until the convict's good health is declared. During the caning process, convicts should wear provided thin clothes that cover the genitals; and be in a standing position without any buffer from men, and a sitting position for women.

There is an indication of the acceptance of the caning punishment, shown by no rejection and rare appeals on the punishment. This implies that the implementation of Islamic law is relatively proper. The acceptance of this punishment is because of its clear and measurable process. 


\section{Implementation of Qänun Jinayat in Aceh}

This study finds that the implementation of sharia Qänun in Aceh from year to year has shown significant progress. This includes the application of Islamic criminal law or Qänun jināyat, along with caning punishment. The table below provides explanations related to the ideals and factual achievements of the application of Islamic law in the Special Province of Aceh. Especially in the field of jināyat (Islamic Criminal Law).

The Recapitulation of Decided, Undecided, Jinayat Cases and Executed Decisions in the High Court of Aceh 2018

\begin{tabular}{|c|c|c|c|c|c|c|c|c|c|c|}
\hline \multirow[b]{2}{*}{ No. } & \multirow[b]{2}{*}{ High Court } & \multicolumn{5}{|c|}{ Type of Case } & \multicolumn{3}{|c|}{ Type of Punishment } & \multirow[b]{2}{*}{ Explanation } \\
\hline & & Khamar & Maisir & $\begin{array}{c}\text { Violation } \\
\text { of } \\
\text { decency }\end{array}$ & Etc. & Amount & Whip & Fine & Confinement & \\
\hline 1. & Banda Aaceh & 5 & 7 & 21 & - & 33 & 28 & - & - & $\begin{array}{c}3 \text { of } \\
\text { cassation, } \\
\text { and } 2 \\
\text { decisions } \\
\text { have not } \\
\text { yet been } \\
\text { executed }\end{array}$ \\
\hline 2. & Sigli & 1 & 3 & 8 & 1 & 13 & 12 & - & 1 & All Executed \\
\hline 3. & Takengon & 1 & 5 & 12 & - & 18 & 16 & - & - & $\begin{array}{c}2 \text { have not } \\
\text { yet been } \\
\text { executed }\end{array}$ \\
\hline 4. & Langsa & - & 8 & 1 & - & 9 & 9 & - & - & All executed \\
\hline 5. & Meulaboh & 8 & 12 & 27 & - & 46 & 19 & & 34 & $\begin{array}{c}44 \text { have not } \\
\text { yet been } \\
\text { executed }\end{array}$ \\
\hline 6. & IDI & 1 & 16 & - & - & 17 & 9 & - & 8 & All executed \\
\hline 7. & Sinabang & - & - & 3 & - & 3 & 3 & - & - & $\begin{array}{l}1 \text { has not } \\
\text { yet been } \\
\text { executed }\end{array}$ \\
\hline 8. & Calang & 1 & - & - & - & 1 & 1 & - & - & $\begin{array}{l}1 \text { has not } \\
\text { yet been } \\
\text { executed }\end{array}$ \\
\hline 9. & Subulussalam & - & 1 & - & - & 1 & 1 & - & - & All executed \\
\hline 10. & Tapak tuan & 1 & - & 4 & - & 5 & 5 & - & - & $\begin{array}{l}3 \text { have not } \\
\text { yet been } \\
\text { executed }\end{array}$ \\
\hline 11. & Lhoksukon & - & 1 & 7 & - & 8 & 2 & - & 7 & $\begin{array}{c}1 \text { cassation, } \\
1 \text { appeal and } \\
6 \text { cases have } \\
\text { not been } \\
\text { executed }\end{array}$ \\
\hline
\end{tabular}




\begin{tabular}{|c|c|c|c|c|c|c|c|c|c|}
\hline \multirow[b]{2}{*}{ High Court } & \multicolumn{5}{|c|}{ Type of Case } & \multicolumn{3}{|c|}{ Type of Punishment } & \multirow[b]{2}{*}{ Explanation } \\
\hline & Khamar & Maisir & $\begin{array}{c}\text { Violation } \\
\text { of } \\
\text { decency }\end{array}$ & Etc. & Amount & Whip & Fine & Confinement & \\
\hline 12. Kuta cane & 1 & 5 & 3 & - & 9 & 9 & - & - & $\begin{array}{c}3 \text { have not } \\
\text { yet been } \\
\text { executed }\end{array}$ \\
\hline 13. Mereudu & - & 1 & - & - & 1 & - & - & 1 & All executed \\
\hline 14. Lhokseumawe & 2 & 3 & 12 & - & 17 & 16 & - & 3 & $\begin{array}{l}1 \text { has not } \\
\text { yet been } \\
\text { executed }\end{array}$ \\
\hline $\begin{array}{l}\text { 15. Simpang tiga } \\
\text { redelong }\end{array}$ & - & 5 & 6 & - & 11 & 11 & - & 1 & $\begin{array}{c}2 \text { have not } \\
\text { yet been } \\
\text { executed }\end{array}$ \\
\hline 16. Jantho & - & 1 & 26 & - & 27 & 19 & - & 8 & All executed \\
\hline 17. Blangkejeren & 7 & 8 & 10 & - & 25 & 23 & 1 & 1 & $\begin{array}{l}1 \text { has not } \\
\text { yet been } \\
\text { executed }\end{array}$ \\
\hline 18. Bireun & 1 & 4 & 2 & - & 7 & 6 & & & $\begin{array}{l}2 \text { have not } \\
\text { yet been } \\
\text { executed }\end{array}$ \\
\hline 19. Singkil & 5 & 6 & 7 & - & 18 & 14 & 1 & 2 & $\begin{array}{l}5 \text { have not } \\
\text { yet been } \\
\text { executed }\end{array}$ \\
\hline 20. Suka makmue & - & - & - & - & - & - & - & - & Null \\
\hline 21. Blangpidie & - & - & - & - & - & - & - & - & Null \\
\hline 22. Sabang & - & - & - & - & - & - & - & - & Null \\
\hline 23. Kuala simpang & 5 & 27 & 2 & - & 34 & 34 & - & - & $\begin{array}{l}2 \text { have not } \\
\text { yet been } \\
\text { executed }\end{array}$ \\
\hline Amount & 39 & 112 & 151 & 1 & 303 & 237 & 2 & 66 & \\
\hline
\end{tabular}

The table above shows that most districts or cities have executed court decisions on criminal cases. A large portion of cases have been decided by the Sharia Courts and have permanent legal force (inkracht). Even though some regencies still have some decisions remain unexecuted, it seems that the delays have been due to technical factors. This cannot be seen as a form of the unwillingness of the local authorities or the rejections of the Qänun Jināyat, Meulaboh Regency and Lhoksukon are the examples.

There was only one regency (5\%) that has never executed a decision of the Sharia Court even though the Sharia Court has granted a caning sentence. Moreover, the decision has had inkracht status, but still, it has not or was not executed. The other 19 districts, in general, have 
had executed the decisions issued by Sharia Courts. For example, in Meulaboh District, the Sharia Court ruled 46 cases, and only 2 cases (4.3\%) had been executed. The most significant part, which is 44 cases (95.6\%), have not been executed, likewise with Lhoksukon, of the 8 cases that have been decided and 6 of them already that have legal force. This is because one case was filed an appealed, and one other has been appealed, but none has been executed.

Even so, there is a need to acknowledge that there are still districts that are incapable or unwilling to apply Qänun Jināyat or to process jinayat cases as regulated in Qànun Jināyat. These districts are Suka Makmue, Belangpidie, Sabang, Calang, Subulussalam, and Meureudu that have never prosecuted jināyat cases occur in their respective jurisdictions. One city and 17 regencies, on the other hand, have proceeded the jinayyat cases. Most of the decisions regarding those cases have been executed.

Thus, as emphasized above, the number of cities or regencies that have imposed the Qänun Jināyat appears to be more significant. From all cities and regencies in Aceh have tried jināyat cases and executed the decisions with inkracht status. In Meulaboh, from 46 decided cases and have inkracht status, there are only two decisions $(4,3 \%)$ that have been executed. The rest of them or 34 decisions $(73,9 \%)$ had not been executed in that year. Lhoksukon, on the other hand, has never executed 6 decisions out of 8 decisions with inkracht status. Two of them are still in the process of appeal and cassation.

The Implementation of Qänun Jināyat by Regencies and Cities in Aceh

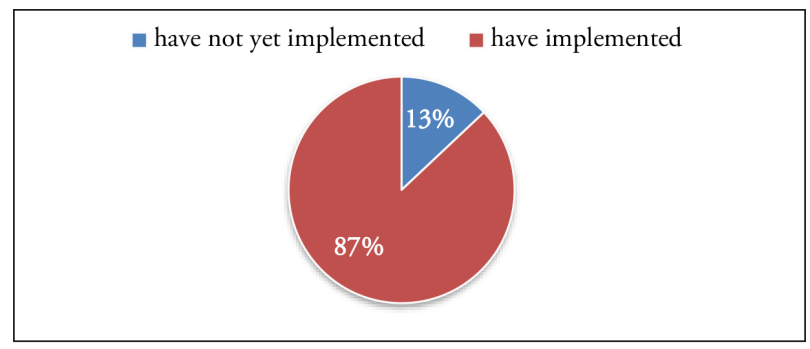

From the above diagram, it can be understood that out of 23 regencies and cities in Aceh, only 3 (13\%) of them have not yet processed 
jināyat cases in their respective jurisdictions to the local Mahkamah Shar'iyya. The three regencies are Sukamakmue, Blangpidie and Sabang. Meanwhile, the other 20 districts or cities (87\%), in general, have applied the Islamic criminal law in various ways.

Second, regencies and cities which are consistent (istiqämah) in processing jināyat cases and executing Mahkamāh Shar'iyya decisions were mainly Banda Aceh, followed by Takengon, Lhokseumawe, Blangkejeren, and Kuala Simpang. For Banda Aceh, out of 33 cases, $28(85 \%)$ of them were executed, while three $(10 \%)$ others are still in cassation. Only two convicts $(7 \%)$ have not been executed. In Takengon, of the 18 decisions, 16 (89\%) of them were executed, and only $2(11 \%)$ remained unexecuted. Whereas in Lhokseumawe, from 17 cases, only one (5\%) decision that has not been executed. The remaining 16 decisions (95\%) have already been executed. In Blangkejeren district, out of 25 cases, 24 (96\%) decisions have been executed; and only 1 (4\%) decisions remained unexecuted. In Kuala Simpang, out of 34 cases, 32 (94\%) decisions have been executed; and only 2 decisions remained unexecuted. Jinayat cases in other districts are generally under 10 cases, and the execution was relatively varied. Some have been executed, while some others have not yet been executed. There were also one or two cases in cassation process.

Third, from the types of jināyat cases violated by convicts, the cases are generally dominated by immoral act cases (151 cases $=49.8 \%)$, accompanied by cases of maysi / gambling ( 112 cases $=36.9 \%)$, khamr or alcoholic beverages (39 cases $=12.8 \%)$, and others $(1$ case $=0.5 \%)$. Look at the diagram below.

Jināyat CASES

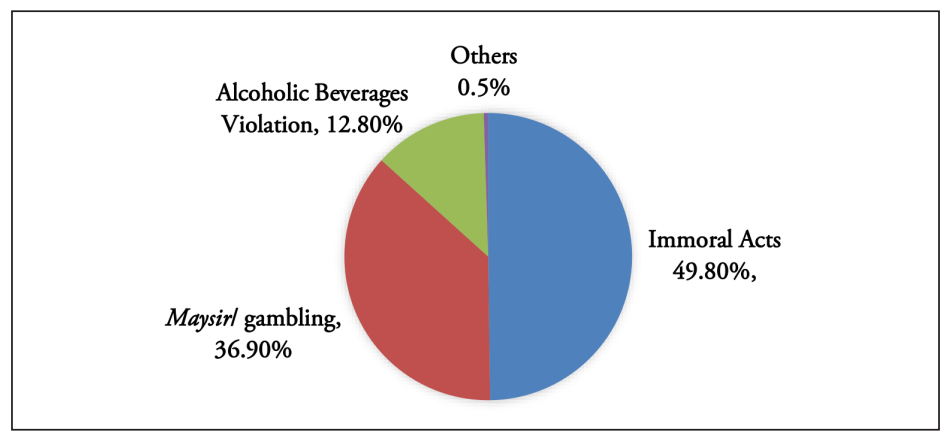


Immorality act cases dominated the jinayyat cases include ikhtilath $(54$ cases $=35.8 \%)$, khalwat 5 cases $=3.3 \%)$, liwath $(1$ case $=0.6 \%)$, sexual harassment $(40$ cases $=26.4 \%)$, adultery $(33$ cases $=21.9 \%)$, rape $(16$ cases $=10.7 \%)$ and facilitating adultery $(2$ cases $=1.3 \%)$ as can be seen in the diagram below:

Immoral Acts

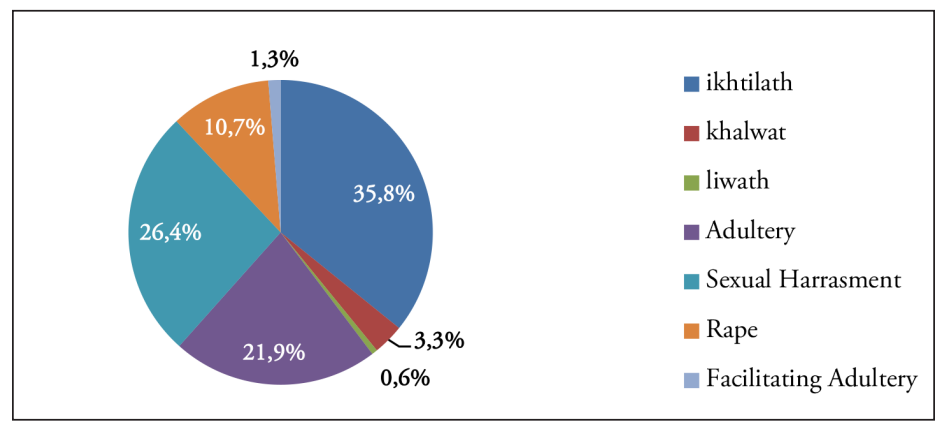

Fourth, from the type of sentence, most of the convicts chose caning as punishment. Of the 303 convicts, 237 (78\%) of them chose caning; only $66(21 \%)$ convicts chose imprisonment, and only 2 convicts chose fines.

Type of Punishment

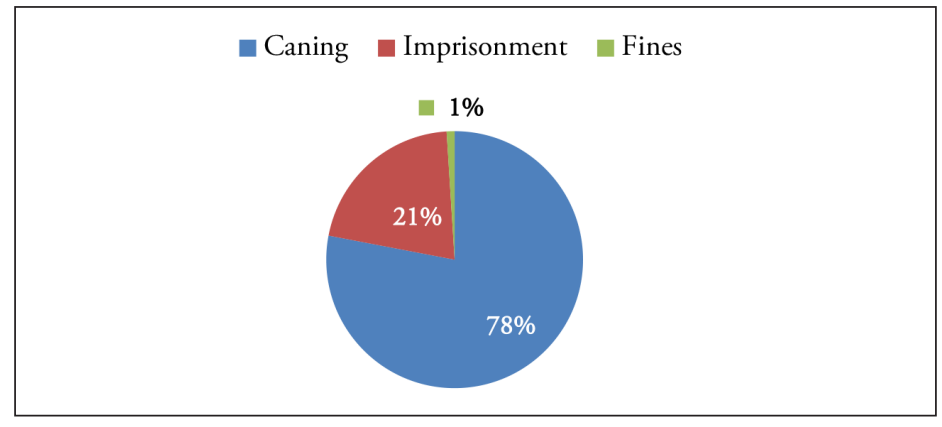

Interestingly, most of the convicts chose canning as punishment. Caning is considered less severe compared to fines and imprisonment. The convicts generally believed that with caning, they could soon move on with their life, then make a living for them and their families. As 
for fines, most of them stated that they do not have money to pay. The imprisonment, on the other hand, is seen as the more severe punishment. Besides, they have to spend a long time (several months and years) in jail; and at the same time, they are separated from their families. Moreover, they will not be able to earn for their living, and their families'; and are overshadowed by the unpleasant situation and even abusive treatment while in prison.

The only 'severe'effect of the caning punishment suffered by the convicts and their families is the shame when the punishment is taking place and when they return to their home. Not to mention that the media reported their executions, and social media spread the news about them. Another impact that becomes the concern of the former convicts is the long term impact on them and their families. For example, the child of the convict can be hard to get a life partner due to his/ her parent's experience with the law.

Another matter that is important to be explained here is that some cases are not processed in the Court. There are still quite a lot of them. Several factors cause this. One of them is the limited number of field officers and their lack of professionalism. The officers have authorities to conduct surveillance and subsequent processes. At the same time, there are some regions with a minimal number of jināyat cases. In general, respondents said that the Qānun Jināyat had not been well implemented as expected. Besides, some of the districts, until this research was conducted (2016) had never carried out caning execution. Some of the districts even have not yet implemented the Qānun . Several obstacles cause this.

Factors that become obstacles for the enforcement of Sharia law in the field of Islamic criminal law can be classified into two big groups, namely internal and external factors. Internal factors include limited funds. Almost all respondents, including the regional governments, acknowledged the limitation in funds, especially the funds, in which the amount is not small. However, there were some cities or regencies that did not find funding as a difficulty.

Next is the lack of facilities and infrastructure, ranging from office facilities to waiting room for the litigants and other involving parties. Sometimes, the sharia authorities borrow facilities from other authorities such as attorney general, police, and so on. Except in some 
cities, including Banda Aceh, Sharia Offices in most cities and regencies do not have separated building to handle jināyat cases.

Since the implementation of Islamic law is still new, the available human resources are also still limited, especially wilāyat al hisbah. Even though the Aceh government has already wilayat al hisbah to enforce sharia, their number is still limited, and their quality needs to be improved. The merging between Municipal Police (Polisi Pamong Praja) and wilayat al hisbah is not easy, even though in many cases the wilayat al hisbah obtain assistance from the municipal police (Al Yasa Abubakar, 2009: 2-20).

Another problem is that there has been a lack of coordination and synergy among institutions involved in the sharia implementation. Some respondents explicitly stated that among the obstacles faced by officers who commit to implementing Qannun Jinäyat is the lack of coordination between authorities, namely police, prosecutors, wilayat al hisbah, Mahkamät Shariyya, etc.

At the same time, there is still an absence of supporting regulations. Even though Aceh has produces 20 sharia Qànun, but the implementation has become difficult because there are no regulations related to technical matters. This contributes to the obstacles of implementing the Qannun, especially by the local authorities. There is also the different interpretation of the legal hierarchy of sharia among other national laws, and the substance of the sharia itself. For example, no regulation limits the number of witness in the process of caning. Because of this, there are too many people who attend the execution, which, in turn, becomes prone to riots caused by provocation. The limitation of witnesses during execution is mentioned in the Quran, Sura al-Nur (24): 2. The limitation of witness in criminal punishment to only the representatives of the society is stated as follow: "walyasyhad 'adzäbahumā thäifatun min al-mu'minin or 'let the execution of the adulterers, men and women, be witnessed by a (small) group of believers.

Another problem is related to supervision, which is still not optimal. In other words, the supervision of people who have been suspected of committing violations against Qānun Jināyat has not been optimal. In addition to the limited number of wilayat al hisbah personnel, the vast area of Aceh province also becomes a challenge for those officers. 
Moreover, there is a possibility that the violators hide their crimes. In this case, community involvement in supervision is needed. The concept of 'a village fence', where young people and the community jointly supervise their areas, can be a solution. If the sharia violators are found, then the villagers will hand them over to the wilayat al hisbah for further processing. This becomes part of community involvement in the implementation of sharia.

However, the commitment of some parties is still in questions. Witnessing the reality and the information from the respondents, it seems that there are still parties and community members who are not ready to accept the implementation of Qänun Jināyat. In this case, the researchers find it challenging to understand the factors cause such reluctance, except the aforementioned factors and economic factor. People reluctance to accept sharia may be due to the protracted legal culture adhered, which is the past domination of the state. This has been shifted into a more democratic culture. However, the concern is still uncritical as no apparent resistance has been found (Samir Fuadi, 2016: 190).

With regards to the socialization of the sharia Qānuns, there have been still minimal attempts to socialize the Qänun. Even though the socialization of sharia Qānun and Jināyat Qänun has been carried out from time to time by the Sharia Office, but it has not reached all levels of Acehnese society, especially those in sub-districts and villages. The socialization of sharia in cities and provincial level is relatively intense, one of which shown by Islamic clothing raids.

Some of the Acehnese people's knowledge about the issue is also still limited. Another contributing factor to the ineffectiveness of the implementation of Jināyat Qänun and other sharia Qānun s is that not all Acehnese people understand sharia in general or sharia Qānun in particular. This is caused by several factors. One of them is the educational background. The socialization process involves the number of parties and needs relatively large funds. That is why the socialization carried out by the authorities has been minimal.

Furthermore, some people are impatient and want the sharia to be quickly implemented comprehensively. This is mentioned by some of the respondents. They stated that there are people who want sharia to be implemented comprehensively and immediately as they 
believe in the beauty of sharia and the fifteen-years'experience of sharia implementation in Aceh (Interview with Al Yasa Abubakar).

As mentioned above, the sharia implementation needs the involvement of the community. However, broader participation has not yet touched all levels. Some of the respondents see positive participation of society, while some of them still see that such participation is still relatively minimum. This can be seen from the fact that some jināyat cases were processed due to reports and complaints from the local community. In some regencies, there was kind of 'intelligence community'consisting of a group of people scattered in places alleged to be the centre for sharia violators, including Qànun Jināyat violators.

There are factors that directly or indirectly lead to the slow implementation of Qänun Jināyat. For example, there have been no regulations that specifically regulate the matter of "extradition" when suspects or even accused fleeing and leaving Aceh or Indonesia. Besides, funding in the extradition process can be a challenge for the authority. Another challenge is related to the safety guarantee for the involving authorities such as police, prosecutors, and judges, as well as involving individuals. Violations of Qānun Jināyat committed by authorities have contributed to the delay in the implementation of the Qänun Jināyat in Aceh (Al Yasa Abubakar, 2008: 13-30).

The external factors include the limited role of media in socializing the sharia in Aceh. Moreover, reports published by the media often lack supports and enthusiasm in reporting the positive side of the implementation of Qànun in Aceh, especially that is related to jināyat (criminal law). Most often, the media reported a negative side of the Qànun Jināyat and showed its negative attitudes towards it. This type of reports has become apparent as there has been an only limited number of local media. It is expected that the media becomes a means to socialize the Qànun Jināyat, as well as other Qänuns.

There are indications that the outsiders, which include people from other Indonesian regions and outside the country, seem unsympathetic towards the application of canning punishment. It often considered against human rights. Such disagreement could be sensed at the beginning of formal sharia implementation in Aceh. National and international media cover the first public canning held by the authority. 
Moreover, some Non-Governmental Organizations show their less objective attitudes towards the sharia and criticize it, especially caning punishment. They come from local and international NGOs. Their reports on the issue seem to be less balanced and sometimes tend to be disproportionate. Even so, this does not mean that sharia implementation in Aceh unsuccessful, let alone failed, considering that the implementation of sharia in Aceh is still ongoing, at least in some parts of Aceh cities and regencies. Another consideration that the sharia implementation in Aceh is relatively new, which is between 4-5 years from the beginning of the first enactment of Aceh Qänun on Jinayat and its procedural law.

Several factors mentioned above lead to an unfavourable impact on the application of Islamic law in Aceh. Among these can cause a sense of pessimism among Acehnese people, including some educated people who seem apathetic and ignorant about the formal implementation of Islamic law in Aceh. The expectation of Acehnese people towards the application of sharia is high, as it considered ideal. The differences in people's attitudes towards that formal sharia application sometimes 'ignitedebates among the Acehnese people, in terms of sharia epistemology, ontology, and axiology. The debates cause the unstainable acceleration of sharia Qànun implementation, especially in the field of Jināyat.

\section{Conclusions}

To conclude, the implementation of sharia in Aceh is the implementation of (sharia) Qànun. If the state has formally implemented the teaching of Islam, then the local government needs to strengthen and implement the Qänun. So far, many Qänuns have been formulated, and their implementation has taken place. However, this implementation has been still not optimal and taken more time than expected. This is because the implementation of the Qanuns depends on the realization of the provincial budgets, which usually takes place every four months.

After the declaration of formal implementation of Islamic law by the Aceh government, various regional institutions have emerged with relatively clear authorities. However, their contribution in strengthening the implementation of Islamic law has been limited, as the socialization to the community has also been relatively limited. In this situation, 
better coordination among governmental organizations in Aceh is needed to strengthen the implementation of sharia-related programs.

Theoretically, there have been more than twenty Aceh Qànuns concerning the implementation of Islamic law. This number is sufficient to be used as a guide in a comprehensive (kaffah) implementation of Islamic law in Aceh alone. Nevertheless, the application of Islamic criminal-related Qānun has not been successful. There are at least two reasons that cause this unsuccessful, which are internal and external factors. These factors mainly related to the limited infrastructure due to limited funding owned by the local government, on one side, and the lack of sufficient operational and technical aspects, on the other.

The leading cause, however, has been the lack of budget provided by the People Representatives of Aceh, and the Aceh government. The implementation of Islamic law in Aceh needs the involvement of local and national government offices, such as police, attorneys, judges from sharia courts, in which their authorities determined by the central government of Indonesia. The weak coordination between the local and central government institutions has still become an issue and hindered the formal implementation of sharia in Aceh, as the issuance of the budget for this matter has also been hampered.

\section{References}

Abbas, Syahrizal, dkk. (2011). Dimensi Pemikiran Hukum dalam Implementasi Syariat di Aceh. Aceh: Dinas Syaiat Islam Propinsi Aceh.

Abd al-Barr, Muhammad Zaki. (I 409H/ 1989M). Taqnin Ushul al-Figh. alQahirah - Mashr: alMaktabah Dar al-Turats.

Abubakar, Al Yasa'. (2008). Syari'at Islam di Provinsi Nanggroe Aceh Darussalam, Paradigma Kebijakan dan Kegiatan. Banda Aceh: Dinas Syariat Islam Provinsi Aceh Darussalam.

Abubakar, Al Yasa. (2019). Syariat Islam di Aceh: Sebagai Keistimewaan dan Otonomi Asimetris (Telaah Konsep dan Kewenangan). Banda Aceh: Sahifah.

Alhudri and Marzuki.(w.y.). Kompilasi Peraturan Perundang-Undangan Tentang Penyidik Pegawai Negeri Sipil Satuan Polisi Pamong Praja dan Wiiayatul Hisbah Aceh, Aceh : Satpol PP dan WH Aceh

Al-Asqalani, Ibn Hajar. (w.y.). Bulugh al-Maram min Adillah al-Ahkam, Surabaya Indonesia: Ahmad bin Sa'ad bin Nabhan.

Al-Asyi, Yusuf Al-Qaradhawi. (2014). Status Aceh Dalam NKRI Pasca MoU Helsinki Menurut Hukum Internasional, Yogyakarta: Grafindo Litera Media. 
Al-'Awaisyah, Husein bin Audah. (1423 H/ 2002 M). al-Mausu'ah al-Fighiyyah alMuyassarah fi Figh al-Kitab wa-al-Sunnah al-Muthahharah, Beirut-Lubnan: Dar Ibn Hazm.

Al-Dasuqi, Muhammad.( 1424 H/2003 M). Manhaj al-Bahts fi-al'Ulum alIslamiyah, Doha -Qathar: Dar al- Tsaqafah.

Al-Duraini, Fathi. (1407 HJ1987 M). Khasha'ish al-Tasyri' al-Islami fi-Siyasah waal-I-Iukm, (w.e.): Mu'assasah al-Risalah.

Al-Fasi, 'Allal. (w.y.). Maqashid al-Syariah al-Islamiyah wa-Makarimiha,(w.e.): Dar al-Gharb al-Islami

Al-Qaradhawi, Yusuf.(w.y.). al-Sunnah Mashdaran li-al-Ma'rifah wa-al-Hadharah. Beirut - Lubnan : Dar al- Syuruq.

Al-Sak'ah, Mushthafa.(1428H/2007 M).al-Farqwa-al-Jama 'ah al-Islamiyyah Islam bi-la Madzahib. al-Qahirah - Mishr: al-Dar al-Mishriyyah al-Lubnaniyyah.

Al-Sularni, Abi Muhammad 'Izz al-Din Ibn 'Abd al-Salam.( 1420H/1999 M). Qawa'id al-Ahkam fi-Mashalih al-Anam. Beirut-Lubnan: Dar al-Kutub alIlmiyyah.

Al-Shan'ani, Muhammad bin Isma'il al-Kahlani.(w.y.) Subul aI-Salam Syarh Bulugh al Maram min Adillah al-Ahkam. Bandung - Indonesia: Dahlan.

Al-Syaukani, Muhammad bin Ali bin Muhammad.( 1402 H/1982 M). Nai alAuthar Syarh Muntaqa al AKhbar min Ahadits Sayyid al-Akhyar. BeirutLubnan: Dar al-Fikr.

Al-Zarqa', Mushtafa Ahmad.(1967-1968). Al-Madkhal al-Fiqhi al-Ami. Damsyik - Siriya: Alif Ba al- Adib.

Al- Zuhaili, Wahbah.( 1409 H/1989 M). al-Figh al-Islami wa-Adilatuh. BeirutLubnan: Dar al-Fikr.

Ambari, Hasan Muarif.( 1419 H/Desember 1998 M). Menemukan peradaban Jejak Erkeologis dan Historis Islam Indonesia. Jakarta: Logos.

Auda, Jasser.(1429 H/2008 M). Maqashid al-Shari 'ah as Philosophy of Islamic Law, London - Washington: the International Institute of Islam in Thought.

Baitaji, Muhammad. (1424 Hl2003 M). Manhaj Umar bin al-Khaththab fi-alTasyri' Dirasah Mustau'ibah li-Figh 'Umar bin al-Khaththab wa-Tanzhimatih. al-Qahirah - Mishr: Dar al-Salam.

Bakhri, Syaiful.( 2010). Ilmu Negara Dalam Konteks Negara Hukum Indonesia, Jakarta- Indonesi: Total Media.

Bisri, Cik Hasan.(2002). Model Penelitian Agama dan Dinamika Sosial, Jakarta Indonesia : Rajawali Press.

Dinas Syariat Islam Propinsi Aceh. (2015). Himpunan Undang-Undang Keputusan Presiden, Keputusan Mahkamah Agung RI, Peraturan Daerah/Qānun. Instruksi Gubernur Berkaitan Pelaksanaan Syariat Islam.

Doi, Abdr Rahman L.( 1412 H/1992 M)., Shari 'ah: The Islamic Law. Kuala Lumpur - Malaysia: A.S Noordeen. 
Faisal, Sanafiah. (2003). Format-Format Penelitian Sosial, Jakarta: PT Raja Grafindo Persada.

Graaf, H.J. De and Th.G.Th. Pigaud.(1985). Kerajaan-Kerajaan Islam di Jawa Peralihan dari Majapahit lee Mataram. Jakarta: PT Temprint.

Hadi, Ainal and Kadriah.( 2009). Eksistensi Mahkamah Syar'iyah Dalam Menjalankan Peradilan di Nanggroe Aceh Darussalam. Aceh: Aceh Justice Resource entr (AJRC).

Hamka (Haji Abdul Malik Karim Amarullah).( 2016). Sejarah Umat Islam PraKenabian Hingga Islam di Nusantara. Jakarta: Gema Insani.

Indonesian-Netherlands Cooperation in Islamic Studies (INIS).( 1995). Islam in Indonesia, A Survey on Events and Developments from 1988 to March 1993. Jakarta: INIS.

Isa Abdul Gani.( 2011). Formalisasi Syari 'at Islam di Aceh (Pendekatan adat, budaya dan Hukum). Banda Aceh: Yayasan Pena Banda Aceh.

Isa, Abdul Gani.(2013). Syari'at Islam Dalam Sorotan dan Solusinya. Yogyakarta: Penerbit Kaukaba.

Ja'far, Ali Muhammad.( 1409 H /1989 M). Tarikh al-Qawanin wa-Marahil al -Tasyrial-Islami. Beirut- Lubnan : al-Mu'assasah al-Jami'iyyah li-al-Dirasat.

Kamali, Mohammad Hashim.( 2008). membumikan Syariah Pergulatan Mengaktualkan Islam. Bandung - Indonesia: Mizan.

Kelsen, Hans.( 2014). Teori Umum Tentang Hukum dan Negara. Bandung Indonesia: Nusa Media.

Khairani.( 2014). Peran Wilayatul Hisbah Dalam Penegakan Syariat Islam (Refleksi 10 Tahun Berlakunya Syariat Islam di Aceh). Banda Aceh: ArRaniry Press.

Lembaga Penjaminan Mutu U1N Syarif Hidayatullah Jakarta, (2015). Pedoman BKD.Jakarta: UIN Syarif Hidayatullah Jakarta.

Lombard, Denys. (1991).Kerajaan Aceh Jaman Sultan Iskandar Muda (1607 1636), terjemahan Winarsih Arifin. Jakarta: Balai Pustaka.

Muhammad, Rusjdi Ali dan Khairizaman.( 2011). Konstelasi Syariat Islam di Era Global. Banda Aceh: Dinas Syariat Islam.

Muhammad, Yusri al- Sayyid. (1421 H/2000 M). Jamial-Fiqh li-al-Imam Ibn Qayyim al-Jauziyyah, [t.k]: Dar al-Wafa'.

Rijal,Syamsul, dkk. (2007). Dinamika dan Problematika Penerapan Syariat Islam, Syariat Islam Provinsi Nanggroe Aceh Darussalam.

Sa'id, 'Abd al-Sattar Fath Allah. (141 H/1992 M). al-Minhaj al-Qur'ani fi-alTasyri'.(w.e.)

Sarong, A. Hamid dkk.( 2003). Kontekstualisasi Syariat Islam di Nangroe Aceh Darussalam Aceh: Ar- Raniry Press.

Sulaiman, 'Abd aI-Rahman Sayyid. (2009). al-Bahts al- 'Ilmi Khuthuwat waMaharat al Qahirah. Mishr: 'Alam al-Kutub. 
Suma, Muhammad Amin. (2004). Himpunan Undang-Undang Islam dan Pelaksanan Lainnya di Negara Hukum Indonesia, Jakarta - Indonesia: Rajawali Press.

Thabari, Muhibbut. (2012). Kedudukan Wilayatul Hisbah di Aceh, $P h D$ Disertastion, Pascasarjana IAIN Ar-Raniry Banda Aceh.

Thalib, Shufi Hasan Abu. (1421 H/2001 M). Tathbiq al-Syari'ah al-Islamiyyah fial-Bilad al-'Arabiyyah, al-Qahirah - Mishr : Dar al- Nahdhah al-Arabiyyah.

Turner, Bryan S.( 1991). Sosiologi Islam Analisis Atas Tesa Sosiologi Weber, Jakarta - Indonesia : Rajawali Press.

Zaenuddin, Muslim, dkk.( 2012). Problematika Hukuman Cambuk di Aceh. Pemerintah Aceh: Dinas Syariat Islam.

Muhammad Amin Suma ${ }^{1}$, Ridwan Nurdin ${ }^{2}$, Irfan Khairul Umam ${ }^{3}$

1,3Universitas Islam Negeri Syarif Hidayatullah Jakarta

${ }^{2}$ Universitas Islam Negeri Ar-Raniry Banda Aceh

E-mail: ${ }^{1}$ aminsuma@uinjkt.ac.id, ${ }^{2}$ ridwannurdinfsh@gmail.com, ${ }^{3}$ irkhum@uinjkt.ac.id 